\title{
JUNO AGAINST WEDDING AND CHILDBIRTH: MEANING AND FUNCTION OF A REVERSED BEHAVIOUR
}

\begin{abstract}
Summary: Juno, the goddess of marriage who is able - in her form of Lucina - to bring children to light, does not appear to be particularly "motherly" in the ancient sources. I will explain this paradox showing that both attitudes are aspects of Juno's control over motherhood and childbirth, which can manifest itself both in a negative and in a positive way. Moreover, I will show how control over motherhood and childbirth is nothing but one of the numerous tasks which the feminea dea par excellence has to perform in order to regulate the roles of the Roman women.
\end{abstract}

Key words: Juno, Juno Sospita, Juno Caprotina, Ino, Amata, Faunus, Hercules, amiculum Iunonis, Roman marriage, Roman motherhood, female initiation rituals

Hera/Juno, the patroness of marriage in both the Greek and Roman world, was also linked to many aspects of motherhood, such as birth and even breastfeeding, as we can see in the chapter by Giulia Pedrucci. As the Greek Hera was related to birth through her daughter Eileithyia, ${ }^{1}$ the Roman Juno was related to birth through Lucina. Indeed, this ancient goddess, whose cult was dated by Varro to the archaic and legendary reign of Titus Tatius ( $L L$ V. 74), was worshipped as the protectress of birth. Eileithyia had been identified with Lucina (D. H. IV. 15). Juno and Lucina were also superimposed during the Republican period and "Lucina" became a very frequent epithet of Juno. Indeed, Varro ascribes a grove (lucus) near the Esquiline hill precisely to "Juno Lucina" ( $L L$ V. 49). The monarchic cult of Lucina recalled by Varro was probably linked to this grove: as we shall see in greater detail below, Ovid also describes a "primordial" cult of Juno Lucina ${ }^{2}$ in this place monte sub Esquilio, at the foot of the Esquiline hill (Fast. II. 429-452). Consistent with this, the Roman temple of Juno Lucina, built in

\footnotetext{
${ }^{1}$ Eileithyia appears as daughter of Hera already in Hom. Il. XI 270-271. and Hes. Th. 921-923.

2 Ovid calls alternatively the goddess "Iuno" and "Lucina" in this passage.
} 
$375 \mathrm{BC},{ }^{3}$ was in the same area. ${ }^{4}$ It may be observed, however, that Hera/Juno's attitude towards her children is depicted as not particularly "motherly" in myths. In the Iliad (XVIII 395-397), for instance, Hera throws Hephaistos out of Mount Olympus since she cannot accept his physical imperfection. Despite that, as Giulia Pedrucci ${ }^{5}$ has demonstrated, specific messages rather then familiar roles were what mostly mattered in these tales: Hephaistos was depicted in myth at the same level as Hera within the rather complex Olympian family, rather than as a "child". Another version of the myth confirms Pedrucci's hypothesis that tales can completely change on the basis of what they want to enhance. Indeed, in another passage of the Iliad (I 572-590) the god was thrown out by Zeus who was angry at Juno, because he had tried to protect her. In this case Juno seems to be a good mother. As such, these myths do not contradict the examined pro-motherhood function of Hera/Juno.

And yet, in certain cases, the same goddess strongly opposes both weddings and childbirth, showing an attitude which evokes ancient demons like Lamashtu and Lilith, in the Near East, Medusa, Lamia and the lamiae in the Greek world and the Roman striges. ${ }^{6}$ I will single out a few examples of such a mechanism of reversal, focusing mostly on the Roman Juno and on the literary sources, and investigating what might have provoked it.

\section{BAD BRIDES AND BAD MOTHERS}

In Greek mythology, two emblematic examples of this attitude are provided by the tale of Herakles' birth and in the story of Leto giving birth to Apollo and Artemis. In both cases Hera strongly opposes the childbirths. As recalled early in the $3^{\text {rd }}$ Homeric Hymn, Apollo's birth lasted nine whole days and nights because Hera had kidnapped her daughter Eileithyia, preventing Leto from having an easy and painless labor. ${ }^{7}$ In the case of Herakles, the first account of Hera opposing his birth is provided by Homer's Iliad (XIX 98-133). We read a detailed account of the Greek myth in Giulia Pedruc-

${ }^{3}$ The chronology is provided by Plin. NH XVI 235.

${ }^{4}$ It may be added that the Etruscan Uni, identified with Juno, in Pyrgi was associated with both Eileithyia and Leucothea: see BLOCH 1969, 58-65; DUMÉZIL-STRUTYNSKI 1980, 129-140 and LITTLEWOOD 2006, 147-148.

${ }^{5}$ PEDRUCCI forthcoming.

${ }^{6}$ The bibliography on these figures, their similarities and (perhaps) connections is fairly rich; see, e. g., BURKERT 1992, 82-87; WeSt 1992, 361-368; BETZ 1997, 45-63; JOHNSTON 2001, 361-387 and the recent BLAIR 2009, 24-30, with bibliography. Lamia, according to the myth, was loved by Zeus. Jealous Hera killed all her children and transformed the woman into a monster hunting and devouring children. On Lamia and the lamiae, who are also mentioned in the Roman sources (see, e. g., Hor. ars poetica I 340 and Ap. Met. I 17. 16 and V 11. 17) and survive in several modern folk traditions, see also the recent PEDRUCCI 2013, with bibliography. Regarding the striges see, first of all, Cherubini 2010. It must be observed, however, that these figures are always against children and motherhood (Lamia, of course, had born children, but in the end she lost them) whereas Hera/Juno, as we have seen, was generally an important patroness of childbirth. Regarding the striges and their relation with Lamia and Lamashtu see also MCDONOUGH 1997, 315-344.

${ }^{7}$ See Pironti-PirenNe-Delforge 2013, 71-91, esp. 72-79. 
ci's chapter. We read a far more recent account of Hercules' birth in Ovid (Met. IX 281-301). Here Juno sends her daughter Lucina who sits out of the room where Alkmene is in labor, and as long as she keeps her legs, arms, and fingers crossed, Alkmene cannot give birth. Ovid's version of the Homeric story shows that the Romans inherited this theme: Juno, who had been identified with the Greek Hera, ${ }^{8}$ and usually supports childbirth in the form of Juno Lucina, in certain circumstances can embody, instead, an anti-motherhood power.

This also occurs in the Roman version of the myth of Ino. As we learn from both Ovid's Fasti (VI 473-528) and Metamorphoses (IV 416-542), Ino was hated by Juno for having been - along with her sister Agave - the most important among the nurses of Bacchus, the child whom Jupiter had with Semele, Ino's sister. In revenge, Juno drove her mad, along with her husband Athamas who, in a frenzy, killed a young son of theirs. Ino fled then with their other son, Melikertes, in her arms, and she leapt off the cliffs into the sea. According to a particular version of the myth quoted in the Fasti (VI 501-528), Ino and her son reached the shores of Italy and the mouth of Tiber. Here, near the Aventine hill, there was a grove inhabited by Italian Maenads (Latias Bacchas). Juno, pursuing her revenge, drove them mad as well, by saying: "O too-easynatured ones, caught by every feeling! This stranger comes, but not as a friend, to our gathering. She's treacherous, and would learn our sacred rites: But she has a child on whom we can wreak punishment". 9 As a consequence, the Maenads kidnapped baby Melikertes, until Hercules, who was driving the Iberian cattle to the riverbank, intervened and entrusted Melikertes back to his mother.

According to an analogous mechanism of reversal, Juno, the goddess of marriage, can express an "anti-nuptial" power. This occurs, for example, in the story of Lavinia and Amata, as narrated by Vergil. In the Aeneid, Latinus' daughter Lavinia is promised to Turnus, king of the Rutuli. Faunus, Latinus' father, insists that the king give her instead to Aeneas (Aen. VII 81-106). Juno, great enemy of the Trojans and Aeneas, does her best to oppose the new wedding. She sends the Fury Allecto to raise queen Amata's rebellion and make her oppose Latinus' plans. Allecto, moreover, is sent to Turnus in order to enrage him. Turnus consequently wages war on Aeneas. Juno, therefore, has the power to make brides, mothers and mother-like figures act in a perverted and dangerous way. By using a modern expression, we could speak of an "anti-social" behaviour.

The story of the Sabine women can be added in order to show Juno's power of preventing successful marriages and motherhood. The Sabine women, in fact, after they had been stolen, did not get pregnant. We find a detailed account of the story in Ovid's Fasti. The events take place in Juno Lucina's ancient lucus:

For there was a day when harsh fate decreed

Wives rarely gave their mates gifts from their womb.

\footnotetext{
${ }^{8}$ Regarding the introduction of Hera in Italy, see MADDOLI 1971, 153-166.

9 Transl. by A. S. Kline (2004) available for any non-commercial purpose at http://www.poetryintranslation.com/PITBR/Latin/OvidFastiBkSix.htm\#anchor_Toc69368011.
} 
Romulus (since it was when he ruled) cried:

'What was the use of raping (rapuisse) the Sabine women,

If that wrong (iniuria) has brought war instead of strength?

It would have been better if our sons were unwed.'

A grove below the Esquiline Hill, untouched

For many years, was sacred to great Juno

(When they had gathered there, husbands and wives

Bowed their knees, alike, in supplication,

And suddenly the tree tops moved and trembled,

And the goddess spoke strange words in her grove:

'Let the sacred he-goat pierce the Italian wives'.

The crowd stood, terrified, at the troubling words.

There was an augur (his name is lost with the years,

But he had lately arrived, an exile from Tuscany),

He killed a he-goat and, at his command, the wives

Offered their backs, to be beaten by thongs from its hide.

When the moon renewed her horns in her tenth orbit,

The husband became a father, and the wife a mother ${ }^{10}$

(Ovid, Fasti II 429-452)

The poet presents these events as the origin of the fertilizing whipping during the Lupercalia, a rite where noble youths ran up and down naked through Rome, striking those they met with shaggy thongs and the hands of women in particular, in order to propitiate their fertility. ${ }^{11}$ Albeit the cause of the Sabines' infertility is not mentioned, it is most likely that Juno has something to do with it. Indeed, only she has the power to put an end to it, and what the goddess suggests in order to break the curse sounds mostly like an expiatory rite. The whipping itself, has a clear expiatory value. ${ }^{12}$ It is performed with strips of goat skin called amiculum Iunonis (Festus 75-76 L), “Juno's mantle", that is to say that the expiation/purification is "in the name of Juno".

Once all these myths have been examined, what can be said regarding this peculiar aspect of Juno? It is fully understandable that a goddess who has a role in the promotion of weddings and the protection of childbirth, according to a mechanism of reversal, can use this very power with an opposite aim. But when and why does it happen so? Which are the circumstances that persuade Juno to act in a reversed and paradoxical way?

${ }^{10}$ Transl. by A. S. Kline (2004) available for any non-commercial purpose at http://www.poetryintranslation.com/PITBR/Latin/Fastihome.htm.

${ }^{11}$ Plut. Caes. 61.

${ }^{12}$ See SCAPINI 2015, 93-109. 


\section{PROTECTRESS OF VIRGINS AND PATRONESS OF MATRONAE}

Let us put in parallel the story of Amata and Lavinia in Vergil, of the Sabine women and of Ino in Ovid's versions. It goes without saying that the three stories are recalled by authors for different reasons and in very different contexts. Nevertheless, all these myths share important elements. They speak of groups of women linked to inaccessible, idyllic and holy landscapes, where strangers are not allowed to enter. Juno's dominion is strong in these places.

Frenzied Amata hides her daughter in mountain woods, frondosis montibus, and protects her virginity by saying that only Bacchus is good enough for her, vociferans solum te, Bacche, virgine dignum (Aen. VII 387-391). Similarly, the other women, who are also driven mad by Juno, search for nova tecta, far from their husbands' houses (VII. 393). The Ausonian Maenads live in a lucus, that is a sacred grove, and they perform rites linked to Juno, since the goddess makes them hostile by saying that the "stranger comes, but not as a friend, to our gathering. She's treacherous, and would learn our sacred rites" (Fast. VI 510-511). From these words we learn that the female gathering and the rites belong to Juno. The Sabine women, in their turn, have to gather in supplication in Juno's lucus, and the goddess gives her oracle from "her woods", per lucos suos (Fast. II 435-440).

Another theme shared by all these stories is the sexual aggression or threat from men or from male gods: Juno will make the heroines behave as anti-brides and anti-mothers precisely as a consequence of such an outrage. More precisely, in the Aeneid Lavinia's virginity is threatened by Aeneas, who is supported by Latinus and Latinus' father Faunus, through his orders, iussa. Amata is well aware of this, as she says "Faunique premunt te iussa parentis" (VII 359-372). As far as the Sabines are concerned, the words Ovid uses to describe the aggression they suffered are, as I have underlined above, rapuisse and iniuria. According to Ovid the Ausonian Maenads feel in danger because of Ino. The latter will be protected by Hercules - the sexual aggressor par excellence in myth - who will chase the Maenads away (Fast. VI 518-522).

The third theme shared by all these myths is the final appeasement of the offended goddess, who consequently makes wedding and motherhood possible. In the Aeneid, Juno eventually agrees that Aeneas will marry Lavinia conubiis felicibus (XII 807-842): the adjective felix implies that this union will be fertile and Lavinia will become a mother. The adventure of Ino also has a positive conclusion, since the Ausonian Maenads fly away and the woman will be worshipped as Leucothea by the Greeks and as Mater Matuta by the Romans (VI 527-548 and especially line 545: Leucothea Grais, Matuta vocabere nostris, "The Greeks will call you Leucothea, our people Matuta"). ${ }^{13}$ It is particularly interesting that the woman whom Juno had made an antimother is now identified with Leucothea/Mater Matuta. Indeed, Mater Matuta was a fertility goddess, whose identification with Dawn symbolized birth. She was also identified with Eileithyia/Lucina and consequently strongly connected to Juno. No more

13 On the cult of Leucothea and her son in Italy, see BONNET 1986, 53-71. 
complete reconciliation with Juno could be imagined. The story of the Romans and the Sabines also implies a "reconciliation" with Juno, since the women are eventually made fertile by means of the amiculum Iunonis, "Juno's mantle", that is the strips of goat skin.

From all this evidence we learn that in Roman mythology Juno's boycott of weddings and motherhood and her support of anti-bride and anti-mother behaviour is always temporary, and occurs in relation to and as a consequence of outrages from men and male gods. I believe, therefore, that the religious conception which lies at the base of these stories regards a temporary opposition between Juno and male gods rather than a conflict between Juno and her she-rivals. As such, the more or less unlucky destinies of heroines such as Ino, Amata and the Sabines are nothing but "side effects" within a divine opposition bigger than they. In the analyzed myths such a relationship implies a male outrage, a phase in which Juno makes the women act in a reversed way and a final reconciliation which restores the order. An important parallel was that of Demeter, who was angry because of the rape of her daughter. The final reconciliation with Hades was also the origin of marriage.

At this point, what can be said regarding the function of Juno in relation to male figures according to the Roman religious thought? The pattern "woman outraged by a man/male god; woman reaction prompted by the goddess; final reconciliation" is typical of myths concerning the goddesses of young women and the parthenoi goddesses in the Greek world, such as Athena and Artemis. ${ }^{14}$ We can recognize this scheme in a number of myths of the Latin and Etruscan communities. ${ }^{15}$ All these stories concern girls raped by Hercules, Faunus, and Mars, who in ancient mythology often appear as prototypes of lovers and progenitors. The same theme is evoked, more or less metaphorically, in the case of the Ausonian Maenads, of Amata and Lavinia (the aggressor is Faunus, albeit indirectly, since Lavinia's virginity is threatened by Aeneas, who is supported by Fauni iussa) and of the Sabines (the aggressor is a sacer hircus, that is to say, again, Faunus, the goat-god: indeed, the Lupercalia are precisely in honor of Faunus). Faunus is here the prototype of the divine ancestor: this role is mostly evident in the Aeneid, where this god is called parens (VII 368). Indeed, in many cases the children born from these rapes will be founders of cities and peoples, as Romulus and

${ }^{14}$ According to the Greek mythology, both Athena and Artemis are virgins, parthenoi: they do not marry and avoid sexual intercourse with men. Both of them were supposed to protect human virgins during several propitiatory ceremonies and/or rituals of passage (for example, the initiation into puberty), such as the Athenian Arrhephoria (dedicated to Athena) and the Arkteia of Attica (in honour of Artemis Brauronia). On the rituals of the parthenoi, see first of all the classic study by BRELICH 1969. On the Arrhephoria see, among others, BURKERT 1966, 1-25; ROBERTSON 1983, 241-88; DONNAY 1997 , 177-205 and PEDRUCCI-SCAPINI 2017. On Artemis and her role in the protection and care of the youngsters see first of all VERNANT 1985. Regarding the Arkteia and other Greek rites of passage in the name of Artemis see, for instance, Stinton 1976, 11-13; MONTEPAONE 1979, 65-76; WALBANK 1981, 276-281 and COSI 2001.

${ }^{15}$ See MAstrocinQue 2014, who deals with this theme. 
Remus, ${ }^{16}$ Pallas, ${ }^{17}$ Latinus $^{18}$ and others. Frequently, however, Hercules, Faunus and Mars have to face warlike goddesses, like Athena (identified with Minerva) and Artemis (identified with Diana), who defended their virginity, or the virginity of their worshippers. The first round of such a conflict often ends with the male god disappointed. It is clear that the anti-nuptial reactions and rebellion prompted by Juno in the myths examined above are to be interpreted in the same way: tricks in order to escape male aggression. ${ }^{19}$

As such, we can conclude that in the Roman religious thought as it is mirrored by the examined sources, Juno was, too, a "parthenos" goddess, a goddess of young girls who was ontologically in conflict with sexually aggressive heroes and male gods. Therefore, her anti-motherly and anti-nuptial traits have to be interpreted in this light. On the other hand, Juno's role was more than this. Indeed, as Faunus, Mars and Hercules tend to achieve their goals in the end, the myths we have examined include not only the part concerning the disappointed seducer, but also a final "chapter" where Juno is appeased and allows wedding and motherhood. I do not intend to discuss here the question as to whether in the Italic world Juno's role as parthenos goddess, protectress of virgins, preceded the role of patroness of the matronae. ${ }^{20}$ In their paper Marialucia Giacco and Chiara Maria Marchetti deal with the archaic implications of the "parthenos" role of Hera with respect to Magna Graecia. What I would like to underline now is that, when our texts were written, the Roman Juno was at the same time both the goddess of virginal status ${ }^{21}$ and the patroness of wifehood and motherhood, conceived as a continuum. She overlooks the whole life process of the Roman women, every stage of their life and every change of status, that is to say every initiation. Therefore, it is not surprising that all these episodes include themes - such as the isolation of women in natural and wild spaces where strangers and men are not allowed and anti-social

${ }^{16}$ Who, as we have already recalled, were children of Rhea Silvia raped by Mars.

${ }^{17}$ Plb. VI 11a 1 = D. H. I 32, 1; cf. D. H. I 43, 1. Pallas was told to be the son of Hercules and Launa, Evander's daughter.

18 Just. Epit. XLIII 1. 9, after Pompeius Trogus, tells how Hercules raped Faunus' daughter and that Latinus was born of this union. Dionysius of Halicarnassus (I 43. 1), ascribes two sons to the hero: Pallas, by Evander's daughter Lavinia, and Latinus, by a Hyperborean girl who was married to Faunus. Cassius Dio (D. C. I 2 Boissevain = Tzetzes, in Lyc.1232) also agrees that Latinus was born from Hercules and Faunus' wife. As we have seen, however, Vergil states that Latinus was the son of Faunus. On these legends see MASTROCINQUE 2014.

${ }^{19}$ On such a dialectic between goddesses/heroines and male gods/heroes, and especially Herakles/ Hercules, see, besides MASTROCINQUE 2014, JOURDAIN-ANNEQUIN-BONNET 1996, and, therein, mostly the studies by Jourdain-Annequin and Giangiulio, focused on the Greek world, and Braccesi.

${ }^{20}$ Anna Pasqualini, on the basis of Cicero, suggests that the warlike Juno, whom she recognizes in the figure of Juno Sospita, was very different from the matronal Juno who sat along with Minerva and Jupiter in the Capitoline temple: the first goddess should be connected to the original Roman and Latin culture, whereas Juno Capitolina was influenced by the Greek Hera (PASQUALINI 2013, 500). Indeed Cicero writes (Nat. I 82): Tam hercle quam tibi illam vestram Sospitam. Quam tu numquam ne in somnis quidem vides nisi cum pelle caprina cum hasta cum scutulo cum calceolis repandis. At non est talis Argia nec Romana Iuno. Ergo alia species Iunonis Argivis alia Lanuinis.

${ }^{21}$ Sharing this role with other virgin goddesses, such as Athena/Minerva, Artemis/Diana and Vesta. 
behaviour - that are typical of female initiations into the status of bride, and not only in the Italic world.

From an anthropological point of view, as Frazer has demonstrated with a number of examples, in the female rites of initiation into the bridal status, virginity and/or temporary chastity were necessary to concentrate the "vital force" in order to benefit the natural processes of growth and stimulate fertility. ${ }^{22}$ It may be interesting to recall that this connection with the growth of animals and plants seems to have been the original function of the Italic Juno, whose name, related to iuvenis and iunior, is related to the Indo-European root * $y u$ which is said to express the idea of "vigor" and "fecundity". ${ }^{23}$ As such, anti-nuptial and anti-motherly behaviour is nothing but a necessary stage in an initiation process which will lead to women's integration into society in the role of matronae. The positive effect of preliminary virginity on subsequent fertility explains the paradox according to which a chaste goddess like Juno - but we may well add Artemis/Diana - is at the same time the patroness of pregnancy and childbirth. ${ }^{24}$ A paradox to some extent analogous characterized Hera's role in archaic and classical Greece. Here, too, as demonstrated by Pironti and Pirenne-Delforge,${ }^{25}$ Hera controlled women and her occasional opposition to childbirths - as it happens in the case of Apollo and Herakles - was not a superficial matter of jealousy, but a form of social regulation. Indeed the goddess, by establishing the exact moment of birth, had the power to make the new born both a legitimate child within a family and more generally a member of a particular oikos. Her role, therefore, strictly concerned questions such as filiation, legitimacy and integration of children into society.

\section{RITUAL CORRESPONDENTS}

Given that ritual and social functions seem to have preceded myths, we could ask now as to whether traces of specific initiations into wifehood and motherhood under the name of Juno - and rituals linked to motherhood and childbirth - can be found in the myths we have examined. One of these rituals was indeed the Lupercalia, whose foundation myth was precisely the story of Romulus and the Sabine women. ${ }^{26}$ The ritual was connected both to Juno and Faunus and therefore strictly evoked their preliminary conflict that preceded the final reconciliation. The ceremony sublimated the mythical male god's aggression through whips made of billy-goat skin which was called, as

${ }^{22}$ FraZER 1911, 107-117. and HARMON 1986, 1909-1973, esp. 1971-1973.

${ }^{23}$ HARMON 1986.

${ }^{24}$ Pironti-PirenNe-Delforge 2013, have studied this very paradox with respect to Artemis, starting from the following question: "Vouée à une virginité qu'elle revendique, quels mécanismes subtils ont-ils associé Artémis à la parturition?" (75).

${ }^{25}$ PirONTI-PIRENNE-DELFORGE 2013, 84.

${ }^{26}$ The Dionysian implications of the Lupercalia should not surprise us, since at a certain point during the Republican Age the Roman female initiations were contaminated by the Dionysism, and a few of them had fully reinterpreted in a Dionysian key, as Jeanmaire and De Cazanove have demonstrated: JEANMAIRE 1970; CAZANOVE 1983, 55-113. 
we have seen, amiculum Iunonis. We have also seen that this ceremony was aimed at producing pregnancy and childbirth: the Roman matronae will become mothers in the name of Juno (Lucina).

The female rituals in honour of Juno Sospita and of Juno Caprotina were the most emblematic initiation rituals in the name of Juno performed by the woman of the Roman and the neighbouring communities. As the Lupercalia, they were also aimed at stimulating fertility.

Propertius describes the ceremony of Juno Sospita in Lanuvium: ${ }^{27}$

Lanuvium, from of old, is guarded by an ancient serpent:

the hour you spend on such a marvellous visit won't be wasted;

where the sacred way drops down through a dark abyss,

the hungry snake's tribute penetrates (virgin, be wary of all such paths!),

when he demands the annual offering of food,

and twines, hissing, from the centre of the earth.

Girls grow pale, sent down to such rites as these,

when their hand is rashly entrusted to the serpent's mouth.

He seizes the tit-bits the virgins offer:

the basket itself trembles in their hands.

If they've remained chaste they return to their parents'arms, and the farmers shout: 'It will be a fertile year' ${ }^{28}$ (Propertius, IV 8. 1-14)

As many studies have demonstrated, this ritual is supposed to propitiate the fertility of human beings, animals and plants. ${ }^{29}$ In this case, virginity, which is protected by Juno, is a preliminary condition for fertility, as happens in our myths. In this case, too, the function of Juno fully expresses itself within a dialectic relationship with Hercules. Indeed, Juno Sospita's iconography makes the goddess a perfect female counterpart of Hercules. As a lion-skin is the dress of Hercules, a goat skin covers Juno Sospita's head. ${ }^{30}$ Moreover, Hercules, too, was worshipped in Lanuvium: $:{ }^{31}$ his presence there, alongside the goddess, was required. The rounds of the fight between Juno and the hero - including a preliminary disappointment of the excited god - are all necessary to the final fertilization and the continuity of the community.

As concerns the feast of Juno Caprotina, it was celebrated on the $7^{\text {th }}$ of July. Plutarch and Macrobius ${ }^{32}$ connect this ceremony to an event that occurred shortly after the Gallic fire. The Latins, perhaps as a pretext for war, demanded from the Romans freeborn virgins in marriage. A Roman serving-maid named Tutula came up with an idea. She told the magistrates to send her to the enemy with other maid-servants, all

${ }^{27}$ Also Ael. Na. XI 16. On Propertius' passage see HARMON 1986, 1965-1973.

${ }^{28}$ Transl. by A. S. Kline (2001/2008) available for any non-commercial purpose at http://www. poetryintranslation.com/PITBR/Latin/Prophome.htm. The line breaks are mine.

${ }^{29}$ PASQUALINI 2013, 508-509.

${ }^{30}$ MASTROCINQUE 2014.

${ }^{31}$ PASQualini 2013, 510-512.

${ }^{32}$ Plut. Cam. 33. See also Plut. Rom. 29 and Macrob. Sat. XI 3-40. 
dressed up like matronae: she had a plan. The magistrates did what they had been told, and sent the girls to the Latins, who had their military camp near Rome. During the night, the maidens stole the enemies' swords, while Tutula climbed a high wild figtree (in Latin caprificus) and made light signals towards Rome. As such, the Roman soldiers attacked the Latin camp and killed a lot of enemies. The feast of the $7^{\text {th }}$ July was supposed to remember that deed. This legend would explain the origin of the sacrifices made on that day by female servants under a caprificus. Plutarch, in Romulus 29, adds that on that day the serving-maidens also run about in companies and strike each other and throw stones at one another, in order to recall their ancient exploit alongside the Roman soldiers. Varro, moreover, mentions a rod, "virga", used by the woman in that circumstance. ${ }^{33}$ The scholars have interpreted this celebration, too, as a ritual of fertility. ${ }^{34}$ Moreover, Pasqualini believes that the tradition concerning the feast of Juno Caprotina points to the ritual of Juno Sospita. Indeed, the name "Tutula" belongs to the same semantic field of "Sospita". ${ }^{35}$ In the legend of Tutula we find many of the themes we have met in the examined myths. We find a threat by men (as observed by Pasqualini, the episode appears to be a sort of reversed analogous of the story of the rape of the Sabines) and men disappointed by the outraged women with the implicit complicity of Juno, so that it is this goddess who will be worshipped after this event.

Therefore, exactly as it happens in the myths, in the ritual of both Juno Sospita and Juno Caprotina, the goddess was supposed to control female virginity and, precisely because of that, and as a consequence of that, grant fertility and the stability of society. ${ }^{36}$ In these cases, too, this function could express itself only in a dialectic relationship with the male element: Hercules in the case of Juno Sospita, the Latins in the etiological myth at the base of the ceremony of Juno Caprotina. The same dialectic may be recognised, as we read in the chapter by Marialucia Giacco and Chiara Maria Marchetti, in the archaic cultural phase of the extra-urban sanctuary at the mouth of Sele river: here, too, Hera was associated with Herakles.

${ }^{33}$ LL VI. 18-19: "The Nonæ Caprotinæ are called so because on that day, in Latium, women sacrificed to Juno Caprotina and performed the ritual under the wild fig-tree (caprificus); they get the rod (virgam) from this tree".

${ }^{34}$ ERKELL 1981, 35-39, esp. 38-39. and MASTROCINQUE 2014. Indeed, the caprificus is considered to be the male fig tree, whose branches are bound to female fig trees so that they can become fruitful. According to Erkell further hints confirm that this tree was linked to fertility. Fig wood was used to carve statues of Priapus, the Roman fertility god par excellence. Moreover, a milky sap flows from the fig's twigs when they are cut. This sap was sometimes used to curdle milk in order to obtain a sort of cheese. Since in the ancient world pregnancy was supposed to be the result of coagulation, in which semen acted as rennet, the fig tree's sap was bound to receive fertility connotations. Therefore, Erkell interpreted Varro's passage mentioned in the footnote above as evidence for a fertility ritual performed by women by means of a virga caprifici.

${ }^{35}$ PASQUALINI 2013, 504-505. On the meaning of Sospes, see HARMON 1986.

${ }^{36}$ In the case of Juno Caprotina, moreover, Juno may support and protect fertility not only of the matronae but also of the Roman female slaves who worship her: her control appears to regard society as a whole. 


\section{CONCLUSIONS}

Let us draw a few conclusions, going back to our starting theme, that is the complex and contradictory connections of Juno to motherhood in the Roman world.

We have discovered that the goddess prompts anti-nuptial and anti-motherly behaviour when her control over women happens to be threatened by men and male gods. We may well call such an anti-nuptial and anti-motherhood attitude as a side effect of initiation. Under this perspective, Juno as a prototype of anti-bride and antimother is not a primary trait of the goddess, but a sort of "derivative function". More specifically, we have seen how chastity and virginity were necessary to concentrate the vital force which granted fertility - of women, but also of nature in general, plants, animals and men included - and therefore social stability. No contradiction between preliminary chastity and consequent wedding and motherhood was perceived, but only a relation of consequence. On the other hand, Juno's promotion of marriage and motherhood also seems to be a "derivative function". It is a consequence of her control over women which is strictly connected to her control over social order and stability. Indeed, the control of women is necessary to social stability, by virtue of the eternal rule that mater semper certa est. This might explain in part the problem at the core of our panel, with respect to the Roman world, that is the paradox that Juno, the goddess of marriage who is able - in her form of Lucina - to bring children to light, does not appear to be particularly "motherly" in the ancient sources. Juno's control over motherhood and childbirth, that can manifest itself both in a negative and in a positive way, is nothing but one of the numerous tasks which the feminea dea par excellence has to perform in order to regulate the roles of the Roman women. First of all, Juno is Regina, meaning that, as persuasively suggested by Daniel Harmon, who focuses on Juno Sospita,

The goddess represented the interdependence of the roles which young men and young women played in the social order. Seen in another way, Juno Sospita is an expression of the interdependence of the social order and the force vitale of nature. ${ }^{37}$

According to this perspective I fully agree with the hypothesis expressed by Giulia Pedrucci that specific messages rather then familiar roles were what mostly mattered in ancient myths. ${ }^{38}$ Although she focuses on the Greek world, her argument is consistent with my conclusions concerning the Roman society: Juno's maternal attitude can change on the basis of what message tales want to convey, which role of Juno they want to enhance, because Juno could be alternatively linked to virgins, brides and mothers. In the Greek world we find interesting parallels of such a complexity. Indeed, as we learn from Pausanias (VIII 22), in Stymphalos Hera was worshipped in three distinct sanctuaries respectively as Pais. "virgin"; Teleia, "fulfilled", that is, as "bride"; and

\footnotetext{
${ }^{37}$ HARMON 1986.

${ }^{38}$ PEDRUCCI forthcoming.
} 
as Chera, "widow". ${ }^{39}$ As we learn from the chapter by Marialucia Giacco and Chiara Maria Marchetti, moreover, during the archaic period at the sanctuary of Hera at the mouth of the Sele River, Hera's function was related to three different cultural spheres: fecundity/fertility, child rearing/initiation, marriage/childbirth. Many centuries later the same functions are all ascribed to Roman Juno at the same time, although by means of different epithets: over the course of the monarchic and republican period many Iunones were born, each of them linked to one traditional female function.

Marianna Scapini

University of Verona

\section{BIBLIOGRAPHY}

BetZ, H. D. 1997: Jewish Magic in the Greek Magical Papyri (PGM VII 260-271). In Schaefer, P. - Kippenberg, H. G. (eds): Envisioning Magic: A Princeton Seminar and Symposium. Leiden-New York-Köln, pp. 45-63.

BLAIR, J. M. 2009: De-demonising the Old Testament. Tübingen

BLOCH, R. 1969: Un mode d'interpretatio à deux degrés. De l'Uni de Pyrgi à Ilithye et Leucothée. Archeologia classica 21, pp. 58-65.

Bonnet, C. 1986: Le culte de Leucothéa et de Mélicerte, en Grèce, au Proche-Orient et en Italie. Studi e materiali di storia delle religioni 52, pp. 53-71.

BRELICH, A. 1969: Paides e parthenoi. Roma

BURKERT, W. 1966: Kekropiden-sage und Arrhephoria. Hermes 94, pp. 1-25.

BURKERT, W. 1992: Lamashtu, Lamia and Gorgo. In Burkert, W. (ed.): The Orientalizing Revolution: Near Eastern Influence on Greek Culture in the Early Archaic Age. Cambridge MA, pp. 82-87.

Calame, C. 1977: Choruses of Young Women in Ancient Greece: Their Morphology, Religious Role and Social Functions. ( $1^{\text {st }} \mathrm{ed}$. in French), Rome

CAZAnove, O. DE 1983: Lucus Stimulae. Mélanges de l'École française de Rome. Antiquité 95, pp. 55-113.

CHERUBINI, L. 2010: Strix. La strega nella cultura romana. Torino

Cosi, D. M. 2001: L'arkteia di Brauron e i culti femminili. Materiali della giornata di approfondimento organizzata dal Seminario avanzato sul tema Il politeismo promosso dall'insegnamento di Storia delle religioni del mondo classico (5 Luglio 2000. Bologna

DonNAY, G. 1997: L’arrhéphorie: initiation ou rite civique? Kernos 10, pp. 177-205.

39 "This cult of Hera Parthenos, either at Hermione in Argolis or at Stymphalos in Arcadia, is never separated from that of Hera Teleia, Hera the Adult": CALAME 1977, 113, where we find further ancient sources. 
DumÉZIL, G. - StRutynski, U. 1980: Camillus: A Study of Indo-European Religion as Roman History. Berkeley-Los Angeles-London

ERKELL, H. 1981: Varroniana. Topographisches und Religionsgeschichtliches zu Varro, De lingua Latina. Opuscula Romana 13, pp. 35-39, esp. 38-39.

FRAZER, J. G. 1911: The Golden Bough. A Study in Magic and Religion. Vol. II. London HARMON, D. P. 1986: Religion in the Latin Elegists. In Aufstieg und Niedergang der römischen Welt II.16.3, pp. 1909-1973, esp. 1971-1973.

Jeanmaire, H. 1970: Dionysos: histoire du culte de Bacchus. Paris

Johnston, S. I. 2001: Defining the Dreadful: Remarks on the Greek Child-Killing Demon. In Meyer, M. - Mirecki, P. (eds): Ancient Magic and Ritual Power. Leiden, pp. 361-387.

Jourdain-AnNEQuin, C. - Bonnet, C. (eds) 1996: Héraclès II. Héraclès, les femmes et le féminin. Bruxelles-Rome

LitTlewood, J. 2006: A Commentary on Ovid's Fasti. Book VI. Oxford-New York

MADDOLI, G. 1971: Il rito degli Argei e le origini del culto di Hera a Roma. La Parola del passato 26, pp. 153-166.

Mastrocinque, A. 2014: Bona Dea and the Cults of Roman Women. Stuttgart

McDonough, CH. M. 1997: Carna, Proca and the Strix on the Kalends of June. Transactions and Proceedings of the American Philological Association (1974-) 127, pp. 315-344.

MONTEPAONE, C. 1979: Il mito di fondazione del rituale munichio in onore di Artemis. Recherches sur les cultes grecs et l'Occident 1, pp. 65-76.

PASQuAlinI, A. 2013: Giunone Sospita ed Ercole a Lanuvio. In Latium Vetus et Adiectum. Ricerche di Storia Religione e Antiquaria [Themata 13]. Tivoli

PEDRUCCI, G. forthcoming: Politeismo e Gender Studies: riconsiderando la maternità di Hera". Paper presented at Velletri IV Incontro sulle Religioni nel Mediterraneo Antico Politeismo. Costruzione e Percezione delle Divinità nel Mediterraneo Antico, 10-14. June 2014.

PEDRUCCI, G. 2013: L'allattamento nella Grecia di epoca arcaica e classica. Roma 2013

PEDRUCCI, G. - SCAPINI, M. 2017: Il ruolo della balia e di altre figure vicarie legate all'infanzia nelle religioni greca e romana: Arreforie e Matralia a confronto. In Pasche Guignard, F. - Pedrucci, G. - Scapini, M. (eds): Maternità e politeismi Motherhood(s) and Polytheisms - Maternité(s) et polythéismes. Bologna

Pironti, G. - Pirenne-Delforge, V. 2013: Ilithye au travail: de la mère à l'enfant. Mètis 11, pp. 71-91

Robertson, N. 1983: The Riddle of Arrhephoria at Athens. Harvard Studies in Classical Philology 87, pp. 241-88.

SCAPINI, M. 2015: Whipping in Myth, Ritual and Magic Practice: a Case of Convergence. In Blanco, M. - Chronopoulou, E. - Suárez, E. (eds): Los papiros mágicos griegos: entre lo sublime y lo cotidiano. Madrid, pp. 93-109.

STINTON, T. C. W. 1976: Iphigeneia and the Bears of Brauron. Classical Quarterly 26.1, pp. 11-13. 
VERNANT, J.-P. 1985: La mort dans les yeux: figures de l'Autre en Grèce ancienne. Paris

WalBanK, M. 1981: Artemis Bear-Leader. Classical Quarterly 31.2, pp. 276-281.

WeSt, D. R. 1992: Gello and Lamia: Two Hellenic Daemons of Semitic Origin. UgaritForschungen 23, pp. 361-368. 